\title{
Inequalities in Earnings and Child Rearing: What is the Gender Aspect of Poverty?
}

\author{
Wolfgang Strengmann-Kubn*
}

\begin{abstract}
Poverty rates of women are usually not or only slightly higher than those of men. Thus the statement "poverty is female" cannot be confirmed empirically. This is at least the case if the typical poverty measures are used. Nevertheless gender inequalities and low pay of women are a main source of poverty. This is shown for the case of Germany by empirical investigations of the relationship between individual earnings and poverty based on household income, both from a crosssectional and a longitudinal point of view. It appears that low earnings of women and reduced work during periods of child rearing are an important reason for poverty, though not only for women, but also for their husbands, even if they work, and for their children.

JEL classifications: $I_{3}, I_{32}, J_{I} 6, J_{13}$

Keywords: gender, poverty, working poor, child care, low pay, discrimination, micro-simulation
\end{abstract}

Women have a lower rate of labour market participation than men, and when they work, earnings are lower. However, the simple conclusion that women thus face a much higher poverty risk cannot be confirmed empirically. The overall poverty rate of women is usually only slightly higher; although the low-wage sector is predominated by women, the majority of the working poor are men. The aim of this article is to explain these apparent contradictions and to show that gender inequalities are nevertheless a main source of poverty.

* Johann Wolfgang Goethe University Frankfurt.

Correspondence address:

PD Dr. Wolfgang Strengmann-Kuhn, Johann Wolfgang Goethe University Frankfurt, Faculty of Economics and Business Administration, PO Box II 19 32, 60054 Frankfurt on the Main, Germany, e-Mail: strengmann@wiwi.uni-frankfurt.de

Received 4 Jul 2006, accepted I7 Jan 2007

(C) INTERVENTION 4 (I), 2007, I75-I94 
I start by discussing the definition and measurement of poverty and its gender aspects (section I). This is followed by an empirical overview about the poverty of men and women, based on German social assistance statistics and the latest Poverty and Wealth Report by the German government (section 2). In the next two parts the relationship between earnings is analysed from a cross-sectional (section 3 ) and a longitudinal (section 4) perspective. In section 3 the paper deals with the working poor, with a special focus on the impact of the low wages and non-employment of women. In section 4 income and earnings are investigated over the life cycle. In this part the main focus is on the consequences of the fact that it is usually mothers who interrupt their professional career to rear children. It becomes apparent that gender inequalities and gender role patterns are not only problematic for women, but also an important source of poverty among working men.

\section{Gender Aspects of Poverty - Definition and Measurement}

To understand the underlying idea of poverty measurement and its gender aspects it is necessary to explain how poverty is defined in general. "Poverty is the counterpart of wellbeing. Hence poverty may also be defined as lack of welfare«, wrote the Dutch economist and poverty researcher Aldi Hagenaars (Hagenaars/van Praag 1985: 140), and elsewhere: "Poverty is a situation in which the welfare, derived from command over resources of a household, falls below a certain minimum welfare level, called the poverty threshold " (Hagenaars 1986: I0). In this sense, poverty is defined as a lack of welfare, which is determined by the resources of an individual. In economic theory "welfare" is one-dimensional (utility). So it follows that someone is poor if (and only if) her individual welfare is below a certain threshold. For measurement, therefore, one has first to decide how to measure welfare and then to choose the poverty threshold or poverty line.

To simplify matters, welfare is dependent on a bundle of consumption goods, material and non-material. The decision about the contents of this consumption bundle depends on individual preferences and disposable resources. There are two, principally different ways to poverty measurement, which are distinguished between a direct approach based on the observed standard of living measured in consumption goods, and an indirect approach based on resources. Predominately the resource definition of poverty is used, which was expressed in the citations above. The argument is that individual preferences, and hence the concrete consumption bundle, should not have an impact on the question as to whether or not someone is poor. However, prompted by several critiques of the indirect approach (see for example Sen I98I, Mack/Lansley 1985), which, in practice, usually amounts to income poverty measurement, over the last 25 years several methods of direct poverty measurement have been developed (Strengmann-Kuhn 2004).

In the following I focus on the standard measurement of poverty, namely relative income poverty. Typically a household's disposable monthly or yearly income is used, measured as the sum of all monetary income from which taxes and social insurance contributions are deducted. Theoretically, non-monetary income like home production or in-kind 
transfers should be taken into account as well as monetary income; this is rarely done, however. Besides the question of which income components are taken into account, the crucial question from a gender perspective is how to extrapolate from (household) income to individual welfare. Related to this is the question as to how different household types compare with regard to their income. This can be measured using what is called equivalent income. Equivalent income is a means-weighted, per-capita household income, which takes into account that children need less than adults, and that larger households enjoy economies of scale. To calculate the equivalent income, household income is divided by the sum of the personal weights, which are represented by an equivalence scale. For a one person-household the weight is one, meaning that equivalent income and household income are identical. The weight assigned to an additional household member usually lies between $O$ and $\mathrm{I}$.

From a gender perspective the two basic assumptions of this procedure are important: I) all income of each household member is pooled (pooling assumption) and 2) this pooled income is then distributed such that each household member receives the same individual welfare (equal sharing assumption). Thus, equivalent income can be interpreted as an individual welfare or utility function under the assumption that each household member enjoys the same level of individual welfare. Hence, either all household members are poor or all household members are not poor. The possibility of unequal distribution between men and women within the household, but also between parents and children, is ignored.

To show the effects of this equal sharing assumption, poverty could be calculated first on the basis of equivalent income, and then on the basis of individual income, and these results compared (Ruspini 1998). An alternative is to assume several distribution rules within the household, and to use simulations to calculate their effects on poverty (Jenkins I99I, Burri 1998). However, theories on within-household distribution (Seel 2002) are rare, and the actual distribution of income within the household cannot be observed. Further, it can be assumed that the kind of redistribution among household members is different for each household. In conclusion, every other distribution rule is just as arbitrary as the equal sharing rule, and yet the opposite assumption that there is no redistribution within the household is even more unrealistic. Thus basing poverty measurement on equivalent income makes sense nevertheless, and thus it was the basis used for the following investigations. However, these should be supplemented by investigations of the extent to which people have control over their own income, and how dependent they are on state or private transfers.

\section{Social Assistance and Poverty in Germany by Gender}

At the end of 2003, 2.8 million people in Germany received social assistance. Of these, I.3 million were male and I.5 million were female, with the distribution by gender largely dependent on age. About one third of social assistance recipients in Germany are children, 
Figure I: Social Assistance Recipients by Gender and Age in 2003

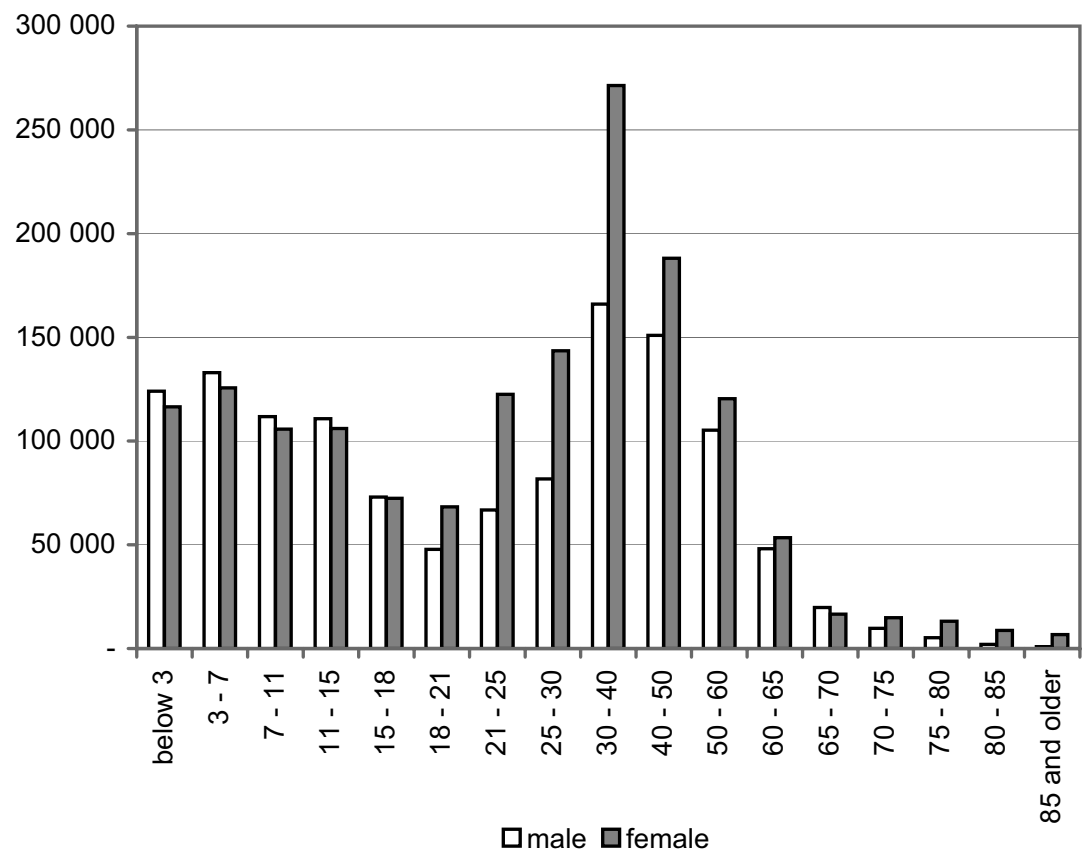

Source: Statistisches Bundesamt 2004

for which the gender distribution is, of course, more or less equal. Women constitute the majority in all of the other age groups (except those between 65 and 70 years). For both genders the majority is middle-aged and the numbers decrease with age (see figure I).

If we look at the relative shares of women rather than absolute numbers (see figure I), it is striking that for the age groups between $\mathrm{I} 8$ and $4 \mathrm{O}$, and in particular between $2 \mathrm{I}$ and 30 , the 60 per cent share of $\mathrm{w}$ omen is quite high. The reason for this is that a high proportion of social assistance recipients in Germany are single mothers. For older age groups this share decreases all the way down to below 50 per cent, but then increases again dramatically: About 60 per cent of the 70- to 75-year-old recipients are women, as are more than 80 per cent of social assistance recipients over 80 . In summary it can be said that social assistance is "female « for the age group between 20 to 40 (single mothers) and in old age (single elderly women). This latter age group, at least, is relatively small in absolute terms.

In sum, 55.9 per cent of all social assistance recipients are women, and moreover, if one looks only at adults, no less than 40 per cent are male. Thus, for social assistance recipients, the statement "poverty is female" is true only in part, and to an even lesser degree for relative income poverty. For the latter we present the results based on two different poverty measures below. In both cases, the basis of poverty measurement is equivalent income, which is calculated for each person (see above). The difference between the 
Figure 2: Share of Female Social Assistance Recipients by Age in \% in 2003

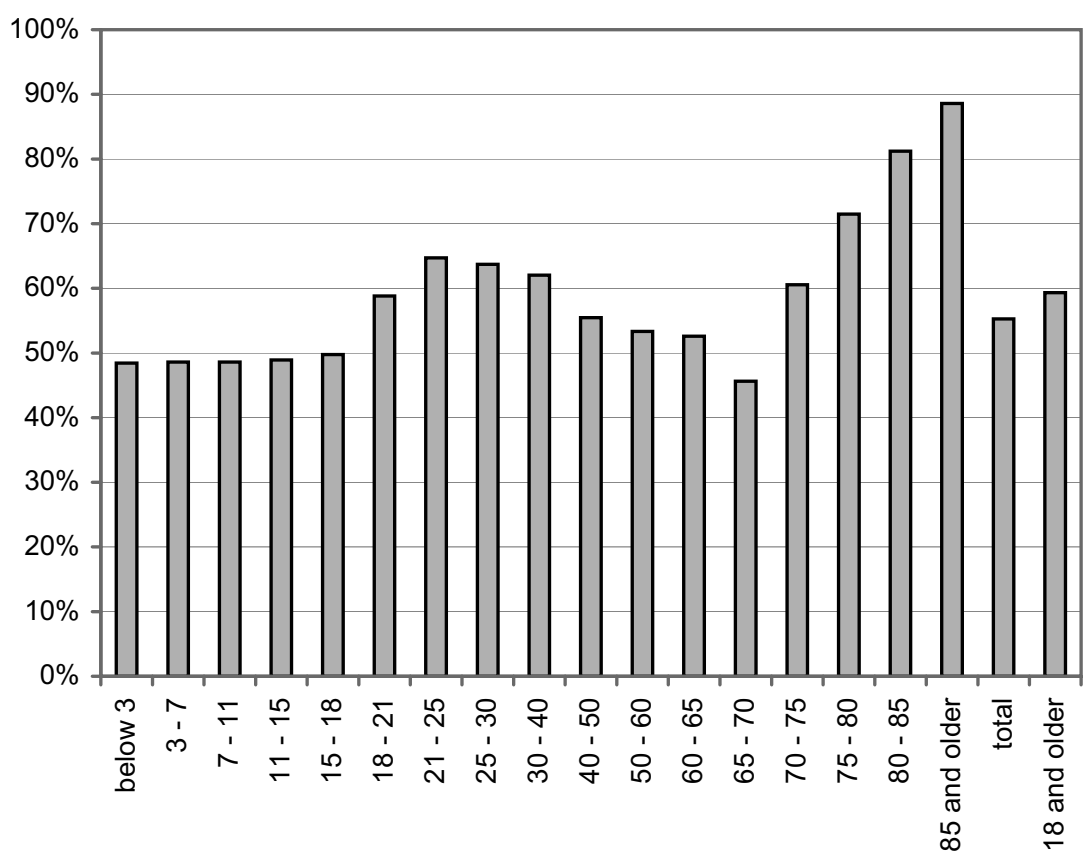

Source: Statistisches Bundesamt 2004

two measures used is the different equivalence scale. The first is the original OECD scale, according to which one adult is assigned a weight of one, a two-adult household has a weight of $\mathrm{I.7}$, and each child increases the weight by 0.5. The alternative used is the modified OECD scale, which functions in basically the same way, but assigns reduced weights to additional household members: adults increase the household weight by 0.5 and children by 0.3. To define a poverty threshold it is customary to use 50 per cent or 60 per cent of the median or 50 per cent of the mean, which usually lies between the 50 per cent and 60 per cent median poverty lines (Hauser/Strengmann-Kuhn 2004).

In Germany, the typical poverty measure was 50 per cent of the mean equivalence income using the original OECD scale, which was, at least at the end of the 1990s, similar to the social assistance threshold for all household types. This was replaced by a new poverty measure, which is now the standard for all EU countries. On the EU level, what is known as the Open Method of Coordination for different areas of social policy has the aim of formulating common goals and quantitative indicators, which are reported regularly by the national states in the form of National Action Plans (NAPs). For the Open Method of Coordination in the field of social inclusion, in 200I the EU Council decided on a number of indicators, the Laeken indicators, named for the location of the Council meeting (Atkinson et al. 2002). The most prominent indicator is the poverty threshold, which is set at 60 per cent of median equivalent income using the modified OECD scale. This 
poverty threshold, which is officially called the "poverty-at-risk threshold ", is referred to below as the »EU poverty line«. The first difference from the former German standard measure is the use of the 60 per cent median instead of the 50 per cent mean. The 60 per cent median poverty line is higher, but only slightly, as the median is lower than the mean.

More important is the kind of equivalence scale used. This does not change the measured extent of poverty very much, but it does alter the measured structure of poverty. Using the modified OECD scale makes the poverty threshold higher for smaller households and lower for larger households, the consequences of which include an overestimated value for poverty of the elderly (Hauser/Strengmann-Kuhn 2004), and lower poverty rates for couples with children. Investigations using a number of poverty measures yield the impression that the results based on the EU poverty line are biased, suggesting that the use of the original OECD scale is more appropriate (Strengmann-Kuhn 2004).

Table I: Poverty Rates in Germany by Gender in \%

\begin{tabular}{l|cccc}
\hline & \multicolumn{2}{|c}{ Original } & OECD Scale & \multicolumn{2}{c}{ Modified OECD Scale } \\
& 1998 & 2003 & 1998 & 2003 \\
\hline Men & 11.6 & 12.9 & 10.7 & 12.6 \\
Women & 12.6 & 13.3 & 13.3 & 14.4 \\
All & 12.1 & 13.1 & 12.1 & 13.5 \\
\hline
\end{tabular}

Source: BMGS 2005: 2I, data source: EVS (Income and Consumption Survey), calculations by Hauser/Becker 2004, poverty line: $60 \%$ of median equivalent income

Table I shows the poverty rates of men and women for the two OECD equivalence scales, using the poverty line at 60 per cent of the median. On the basis of the original OECD scale, the poverty rates of men and women are nearly identical. According to the second Poverty and Wealth Report of the German Government (BMGS 2005), the poverty rate of women was 13.3 per cent in 2003, which is only slightly higher than the I2.9 per cent rate for men. This result that the poverty rates of men and women are so close is initially surprising, as we established above that the poverty line is similar to the social assistance threshold. The reason why the poverty rates of men and women are more close than the social assistance rates lies in differing non-take-up of social assistance for different groups which is particularly low for single parents but high for the elderly and for families with two parents, especially if at least one parent is working (Strengmann-Kuhn 2003: I8o ff., Becker/Hauser 2005, Kayser/Frick 200I). In these two-parent families men and women are affected equally by poverty, while single parents are usually women. Therefore the share of women among social assistance recipients is higher than among the poor population, and this difference is not compensated by the lower share of elderly women, who comprise a much smaller group.

Using the modified OECD scale, the difference in poverty risks is greater, with men at I2.6 per cent, and women at I4.4 per cent. The reason for this is that single elderly 
women have a very high poverty rate using this measure, while the poverty risk for single parents is equally high, independent of measurement.

\section{The Working Poor}

As expressed above, one might expect that the share of women among the working poor would be high because of the differences in employment income between men and women. However, this supposition fails empirically (see table 2). Using the poverty threshold that was customary in Germany ( 50 per cent of the mean, original OECD scale), data from the 1996 Mikrozensus, a one-percent sample of the German households, revealed that male and female workers have the same poverty rate of 5.5 per cent. Since the employment rate of men is higher than that of women, the majority of poor workers is also male. These results can be observed over a longer period as well. This changed only slightly in the I990s, with the poverty rate of women sometimes slightly higher than that of men, and sometimes slightly lower (Strengmann-Kuhn 2003: 87).

Table 2: The Working Poor and Poverty Rates of Workers by Gender (Is to 65-year olds only) in \% in 1996

\begin{tabular}{l|cccccc}
\hline \multirow{2}{*}{} & \multicolumn{2}{|c}{ Poverty rates } & \multicolumn{4}{c}{ Structure } \\
& Workers & All & $\begin{array}{c}\text { Poor } \\
\text { workers }\end{array}$ & All poor & All workers & $\begin{array}{c}\text { Whole } \\
\text { population }\end{array}$ \\
\hline Men & 5.5 & 10.4 & 57.6 & 48.6 & 57.6 & 50.7 \\
Women & 5.5 & 11.3 & 42.4 & 51.4 & 42.4 & 49.3 \\
Total & 5.5 & 10.9 & 100.0 & 100.0 & 100.0 & 100.0 \\
\hline
\end{tabular}

Source: Strengmann-Kuhn 2003: 80, data basis: Mikrozensus 1996, own calculations

To investigate the reasons for this initially so surprising result, it makes sense to analyse the income distribution process (see figure 3), which starts with individual gross earnings and ends with net household income. At each intermediate stage it will be checked whether or not income is sufficient.

On the basis of the German Socio-Economic Panel (GSOEP) for 1998, I2.8 per cent of all individuals who work (including self-employment, part-time and minor employment) have gross earnings below the poverty threshold. Thus, these persons are dependent on private or social support. For net individual earnings this share rises to I8.3 per cent. This means that 5.5 per cent of all workers have gross earnings above, but net earnings below the poverty line. The next step is to analyse the net earnings of the household. The question is then whether the total earnings of the household as a whole are sufficient to avoid poverty, poverty being defined as net equivalent earnings below the poverty line. In this sense, I8.2 per cent of all workers are "earnings-poor «. Thus the rate before and 
Figure 3: The Income Distribution Process and Poverty

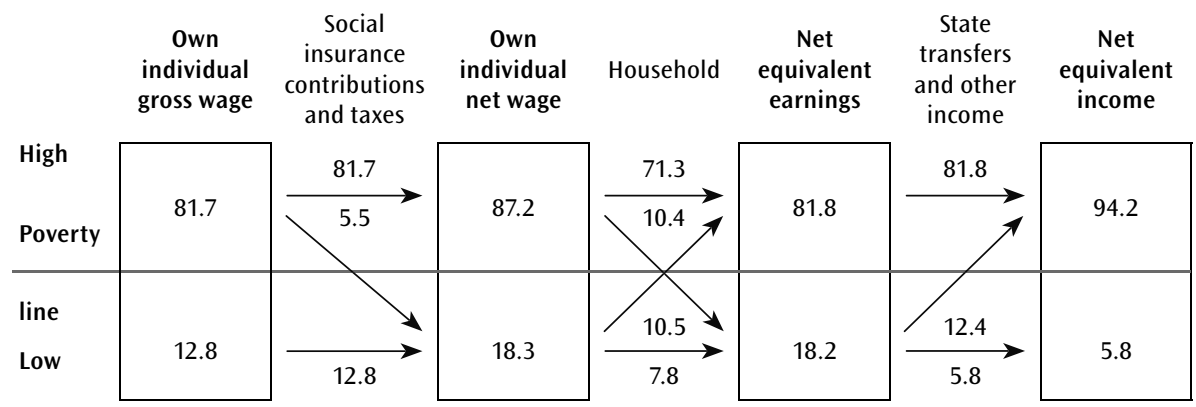

Source: GSOEP I998, own calculations, see Strengmann-Kuhn 2003: I0I

after redistribution within the household is nearly the same, but the resulting groups are by no means identical.

Of the I8.3 per cent workers whose own earnings lie below the poverty threshold, more than half (IO.5 per cent) live in a household with household earnings above the poverty line, because there are other household members with higher earnings. On the other hand, there are nearly as many workers whose own earnings are above the poverty threshold, but whose earnings are not sufficient for all household members.

These results show that the level of individual earnings cannot necessarily reveal anything about poverty. Besides the household context, this is also due to additional income, to capital income and to private and, most important, state transfers. The effect of this additional income is shown in the transition from the third to the fourth stage in figure 3. Of the I8.2 per cent of all workers living in an earnings-poor household, less than one third ( 5.8 per cent of all workers) live in a household with total net household income below the poverty line. These are defined as the working poor.

Table 3: Workers' Paths to Poverty I998

\begin{tabular}{l|ccc}
\hline & $\begin{array}{c}\text { Share among all } \\
\text { workers } \\
\text { (in \%) }\end{array}$ & $\begin{array}{c}\text { Share among the } \\
\text { working poor } \\
\text { (in \%) }\end{array}$ & $\begin{array}{c}\text { Absolute number } \\
\text { (in thousands) }\end{array}$ \\
\hline All working poor & 5.8 & 100.0 & 2,195 \\
\hline Cause of poverty & 2.3 & 39.0 & 856 \\
Low pay & 0.8 & 14.7 & 322 \\
$\begin{array}{l}\text { Taxes, social insurance } \\
\text { contributions }\end{array}$ & 2.7 & 46.3 & 1,017 \\
\hline Household context & 6,485 & & 386 \\
\hline Unweighted case numbers
\end{tabular}

Source: Strengmann-Kuhn 2003: 103, data basis: GSOEP 1998, own calculations 
The income distribution process in figure 3 shows three possible paths to poverty. First, there are workers whose gross earnings are already below the poverty line, and poverty is avoided neither in the household context nor through additional income other than earnings. This group, whose poverty is the product of low pay, consists of about 900,000 people, or about 40 per cent of the working poor (see table 3). Second, there are workers with gross earnings above and net earnings below the poverty threshold, and again poverty is avoided neither in the household context nor through additional income. These workers become poor due to taxes and social insurance contributions. Their share of I4.7 per cent among the working poor and 0.8 per cent among all workers is comparatively low, but nevertheless their absolute number is about 300,000. Third, about half of the working poor have individual net earnings of their own which are above the poverty threshold, and thus become poor because of the household context.

The total number of the working poor in Germany can be divided into two large groups. Half are workers with net earnings below the poverty threshold, who are designated below as workers with (net) poverty earnings. The other half are workers who do not have poverty earnings, but become poor due to the household context. These two groups are structured differently, as will be discussed in the following for distribution by gender.

Table 4: Poverty of Low-earning Workers by Gender in \% in 1998

\begin{tabular}{l|cccccc}
\hline & All workers & $\begin{array}{c}\text { Workers with poverty } \\
\text { earnings }\end{array}$ & $\begin{array}{c}\text { Working poor } \\
\text { with poverty } \\
\text { earnings }\end{array}$ & $\begin{array}{c}\text { All } \\
\text { working } \\
\text { poor }\end{array}$ \\
& Structure & $\begin{array}{c}\text { Poverty } \\
\text { earnings rate }\end{array}$ & Structure & $\begin{array}{c}\text { (Conditional) } \\
\text { Poverty rate }\end{array}$ & Structure & Structure \\
\hline Total & 100.0 & 18.3 & 100.0 & 17.0 & 100.0 & 100.0 \\
Men & 57.7 & 10.0 & 31.5 & 27.4 & 50.8 & 59.6 \\
\hline Women & 42.3 & 29.6 & 68.5 & 12.2 & 49.2 & 40.4 \\
\hline
\end{tabular}

Source: Strengmann-Kuhn 2003: 132, data basis: GSOEP 1998, own calculations

As mentioned, I8.3 per cent of all workers have net individual earnings below the poverty line. However, this is the case for only io per cent of male workers, but for 30 per cent of female workers. Consequently, two thirds (68.5 per cent) of all workers with poverty earnings are women. As shown above, low pay does not necessarily mean poverty. On the one hand, at 17 per cent the poverty rate of workers with poverty earnings is relatively high; on the other hand, this figure means that 83 per cent are not poor. This is more often the case for women, whose (conditional) poverty rate of 12.2 per cent is significantly lower than the poverty rate of 27.4 per cent for men with poverty earnings. The reason for this is that women are more likely to live with a higher-earning man than the other way round. The consequence is that half of the low-paid working poor in Germany are men.

While two thirds of workers with poverty earnings are women, about two thirds (63.6 per cent) of workers with non-poverty earnings, i.e. monthly earnings above the poverty line, 
Table 5: Poverty of Workers With Non-poverty Earnings by Gender in \% in 1998

\begin{tabular}{l|ccc}
\hline & $\begin{array}{c}\text { All workers with } \\
\text { non-poverty earnings }\end{array}$ & $\begin{array}{c}\text { (Conditional) Poverty } \\
\text { rate }\end{array}$ & $\begin{array}{c}\text { Working poor with } \\
\text { non-poverty earnings }\end{array}$ \\
\hline All & 100.0 & 3.3 & 100.0 \\
Men & 63.6 & 3.6 & 69.6 \\
Women & 36.4 & 2.7 & 30.4 \\
\hline
\end{tabular}

Source: Strengmann-Kuhn 2003: I45, data basis: GSOEP I998, own calculations

are men. Only 3.3 per cent of all workers with individual earnings above the poverty line are poor, with only slight differences between men and women. Therefore the shares of poor men and women with earnings above the poverty line are similar compared to the group of all men and women with earnings above the poverty line: about 70 per cent are men and 30 per cent are women (see table 5 ).

Table 6: Falling Below the Poverty Threshold due to Non-employed Household Members in $\%$ in 1998

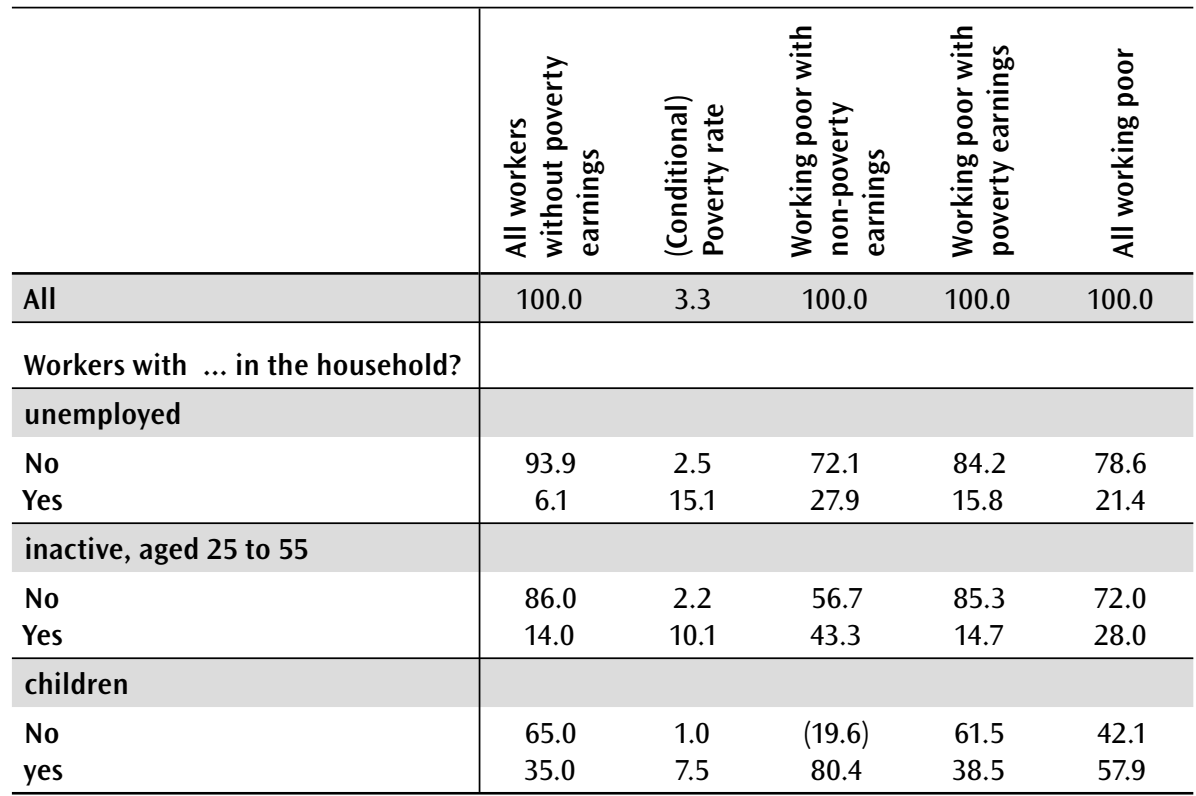

Source: Strengmann-Kuhn 2003: I42, data basis: GSOEP 1998, own calculations

This group of the working poor becomes poor because there are additional household members who earn nothing or very little. One reason for this is unemployment. Table 6 shows that workers who live with an unemployed person do indeed have a relatively high 
poverty rate of I5.I per cent, and that ultimately about one fourth of the working poor with non-poverty earnings are affected indirectly by unemployment. This is particularly often the case in eastern Germany (Strengmann-Kuhn 2003: I66ff.). Unemployment of other household members is only one cause for the poverty of workers, however. More frequent is the case that workers who become poor because of the household context live with an adult of primary working age between 25 and 55, who is out of the labour force (»nactive "), and thus classified as neither unemployed nor employed. This is the case for 43.3 per cent of the working poor whose own earnings lie above the poverty threshold. A typical constellation, particularly for western Germany, is a couple with a working husband and a wife out of the labour force, often due to children in the household. More than 80 per cent of the working poor with individual earnings above the poverty line have children, and 57.9 per cent of all working poor do. Thus the poverty of workers and child poverty are strongly linked.

The majority of the working poor are men, yet a main reason for their poverty is the non-employment of their partners. Table 7 shows the poverty rates by household type and employment constellation. In general, workers in two-adult households with children have lower poverty rates than working single parents. However, for the constellation men with full-time employment/women not employed, which is still particularly common in western Germany, the poverty rate of I4.5 per cent is very high, even higher than the I2.I per cent poverty rate for full-time employed single parents. Thus, full-time employment for one household member is often not enough to avoid poverty when children are involved. However, the poverty rate decreases significantly with any additional part-time employment. The poverty rate for a couple with a man working full time and a woman working part time is only 4.0 per cent.

\section{Table 7: Poverty Rates for Workers with Children by Household Type and Employment Constellation in \% in 1998}

\begin{tabular}{l|c}
\hline & Poverty rate \\
\hline Whole population & 11.5 \\
\hline All workers & 5.5 \\
\hline Single parents & 18.4 \\
full time & 12.1 \\
less than full time & 30.6 \\
\hline Couples with child(ren) & 7.7 \\
both full time & 4.1 \\
man full time/woman less than full time & 4.0 \\
man full time/woman not employed & 14.5 \\
others & 24.2 \\
\hline
\end{tabular}

Source: Strengmann-Kuhn 2003: 165, data basis: GSOEP 1998, own calculations 


\section{Income and Earnings Over the Life Cycle}

In the following we describe the effects of interrupted work careers or the reduced employment of women on total lifetime earnings. An important reason that women work fewer hours or not at all is child rearing. This leads, first of all, directly to lower income. In addition, human capital shrinks in such periods with the consequence of lower earnings in the future (Beblo/ Wolf 2000 and 2002), increasing the existing wage discrimination against women. Thus family income is lower after the period of child rearing than it would be without children. To quantify these effects, lifetime earnings are simulated for men and women with and without children. Furthermore we distinguish between three education types: low education (Hauptschule plus vocational training), middle education (Realschule or Abitur plus vocational training) and high education (post-secondary degree). Note that we focus only on these three groups, i.e. we do not investigate men and women with even lower education, who completed neither school nor vocational training. To simulate lifetime earnings, a wage equation and a labour supply function are estimated empirically and then the resulting earnings are calculated for each age from I8 to 60 (StrengmannKuhn/Seel 2004). Then the earnings of men, for whom we assume that there are no differences between fathers and men without children, are compared with earnings of women with and without children. Because the simulations are based on data from I99I to 2000 from the German Socio-Economic Panel (GSOEP), all values are still measured in DM.

The focus of the investigation is on "typical« life cycles and work careers. Therefore we assume that people are educated first, then enter the labour market, then marry and have exactly two children, and remain married at least until the age of 60 . Further we assume that husband and wife have the same level of education and are exactly the same age, which is relevant because we assume that the labour supply decision of a woman is also dependent on her husband's wage. For men, we assume that they are permanently employed. Our assumptions for "typical « cases posit relatively linear, positive life courses devoid of unemployment, divorces, single parenthood or other problems. This means that the income profile may look worse in reality than for the cases in our simulations.

For the group with low education, the simulation yields the following results (see figure 4). Until the age of $I 7$ all are in education and no earnings are received. At the age of 18 they start to work. The starting wages of men are much higher than those of women. However, the wages of women rise faster with increasing labour market experience, but stay below those of men during the entire lifetime, even for women without children. At the age of 22 low-educated men and women marry and have their first child one year later. The consequence is that the mother reduces to part-time work until the first child goes to preschool at the age of three. Then there is one year of full-time employment before the second child is born. During this one year of full-time employment, mothers earn 150 $\mathrm{DM}$, or about five per cent, less than women of the same age without children, who are continuously employed full time. After the birth of the second child the low-educated woman stops working for three years. When the first child starts school, she re-enters the labour market, but for the time being only part-time, and she does not work full time 
again until the second child starts school. By this time her monthly earnings are 400 DM below the earnings of a woman of the same age without children. In the following years this difference decreases, but it takes 20 years for it to fall back to I50 DM. At the age of 55 , low-educated women with and without children reduce to part-time work, which corresponds to the actual empirical data insofar as there is not an increase in part-time work, but an increase in non-participation, while a large share of women still works full time. In the simulation, this averages out to part-time work.

\section{Figure 4: Simulation of Gross Monthly Earnings of Low-educated Men, Women Without Children and Women With Children (in DM)}

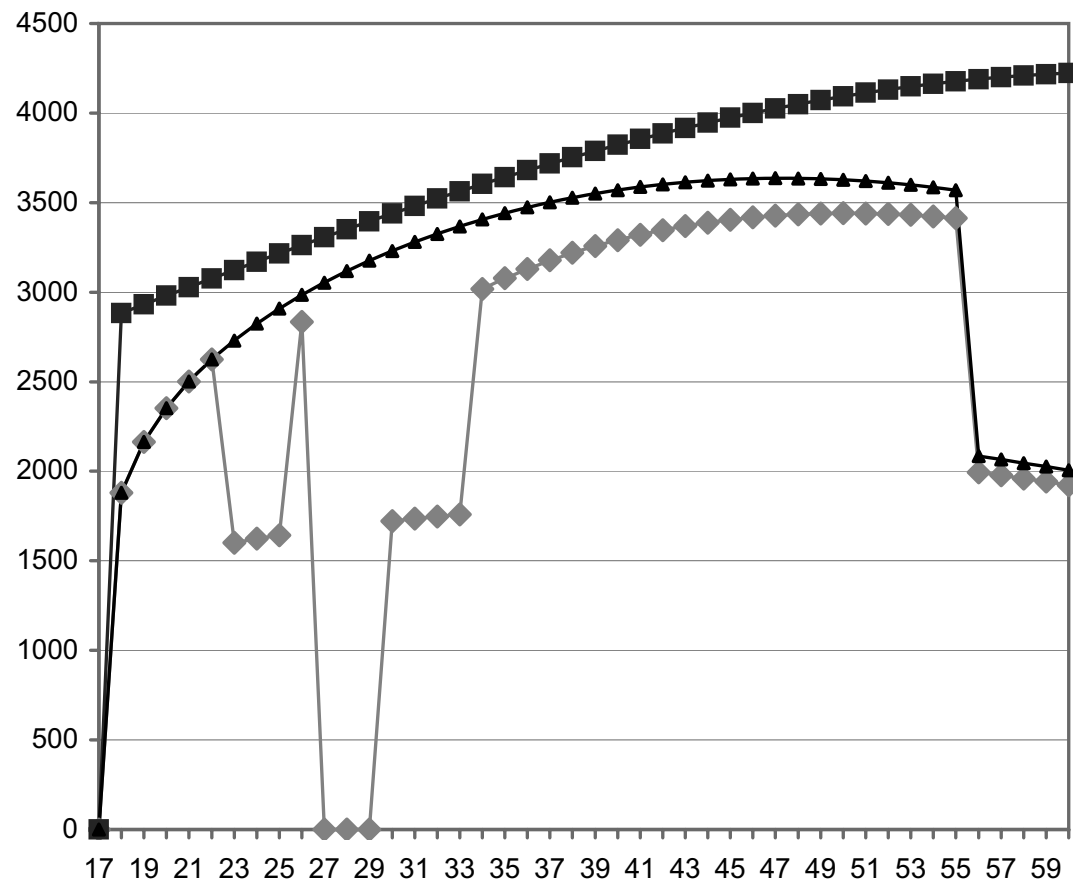

$\longrightarrow$ Women with two children - Men $\longrightarrow-$ Women without children

Source: Strengmann-Kuhn/Seel 2004: 59, data basis: SOEP I99I-2000, Germans residing in western Germany

We simulate similar earnings courses for women with intermediate and high education (see figure 5). Their education takes longer, births are later and the labour supply responses are somewhat different. For intermediate education the interval between the first and the second birth is, again, four years. However, the mother does not stop working after the second child is born, but takes up minor employment of less than is hours per week. For high education, the children are born later, but the interval between them is reduced to three years. Therefore there is no year of full-time work between the births of the first and the 
second child, as simulated for the other education groups. As for intermediate education, the high-educated mother, too, is continuously employed, but she reduces to part-time work after the birth of the first child, and to minor employment after the second is born.

Figure 5: Simulation of Gross Monthly Earnings of Men With Intermediate and High Education, Women Without Children and Women With Children (in DM)

\section{Intermediate Education}

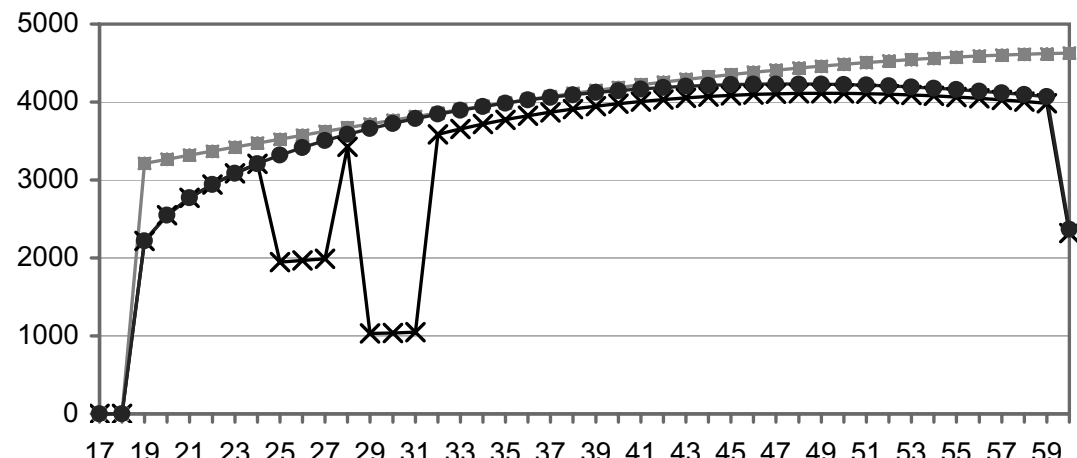

High Education

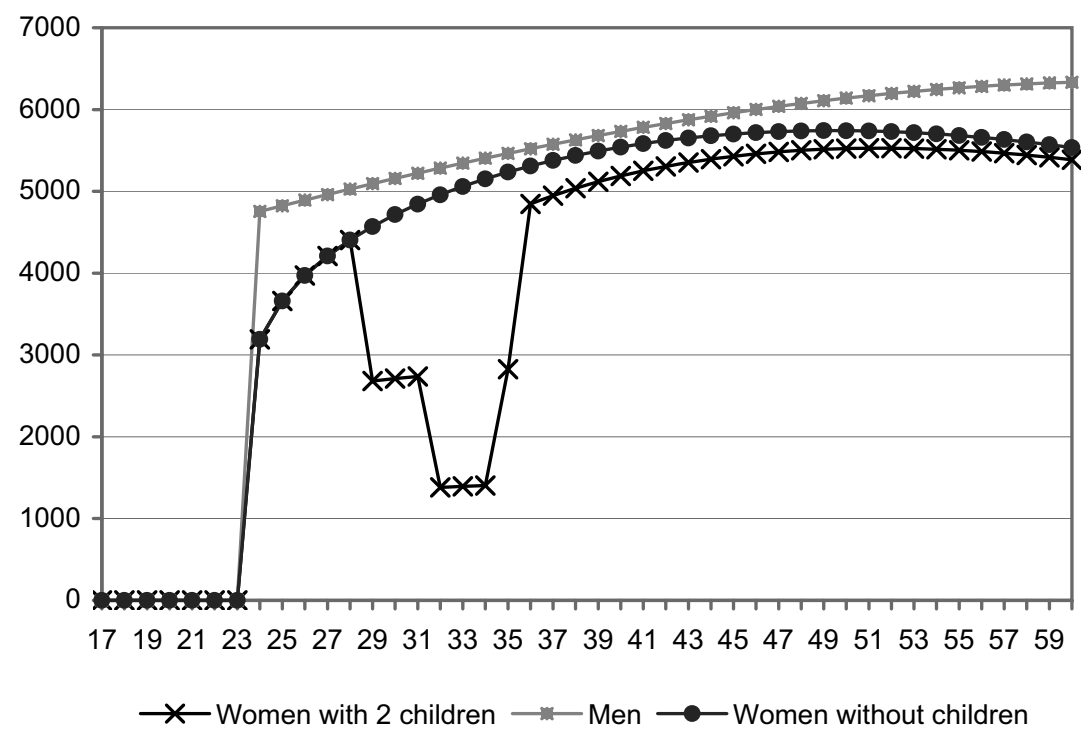

Source: Strengmann-Kuhn/Seel 2004: 6I, data basis: SOEP I99I-2000, Germans residing in western Germany 
Lifetime earnings are calculated by simply adding up the simulated monthly earnings. Men with low education receive a total of 2.I million DM, men with intermediate education 2.3 million DM and men with a post-secondary degree 2.8 million DM (see table 8). Women without children, for whom we simulate continuous employment in each case, receive lower lifetime earnings than men with the same education: between I30,000 DM (or 5.8 per cent) less for intermediate education, and 300,000 DM (or Is per cent) less for low education. This is the pure gender effect. For women with children there is an additional "child effect «, which is the result of work interruptions or working-time reductions for child rearing. This child effect can be divided further into a direct employment effect, caused by lower labour market participation, and an indirect wage effect due to the reduction in human capital caused by lower labour market experience.

Table 8: Simulated Gross Lifetime Earnings, Earnings Gaps and Discrimination

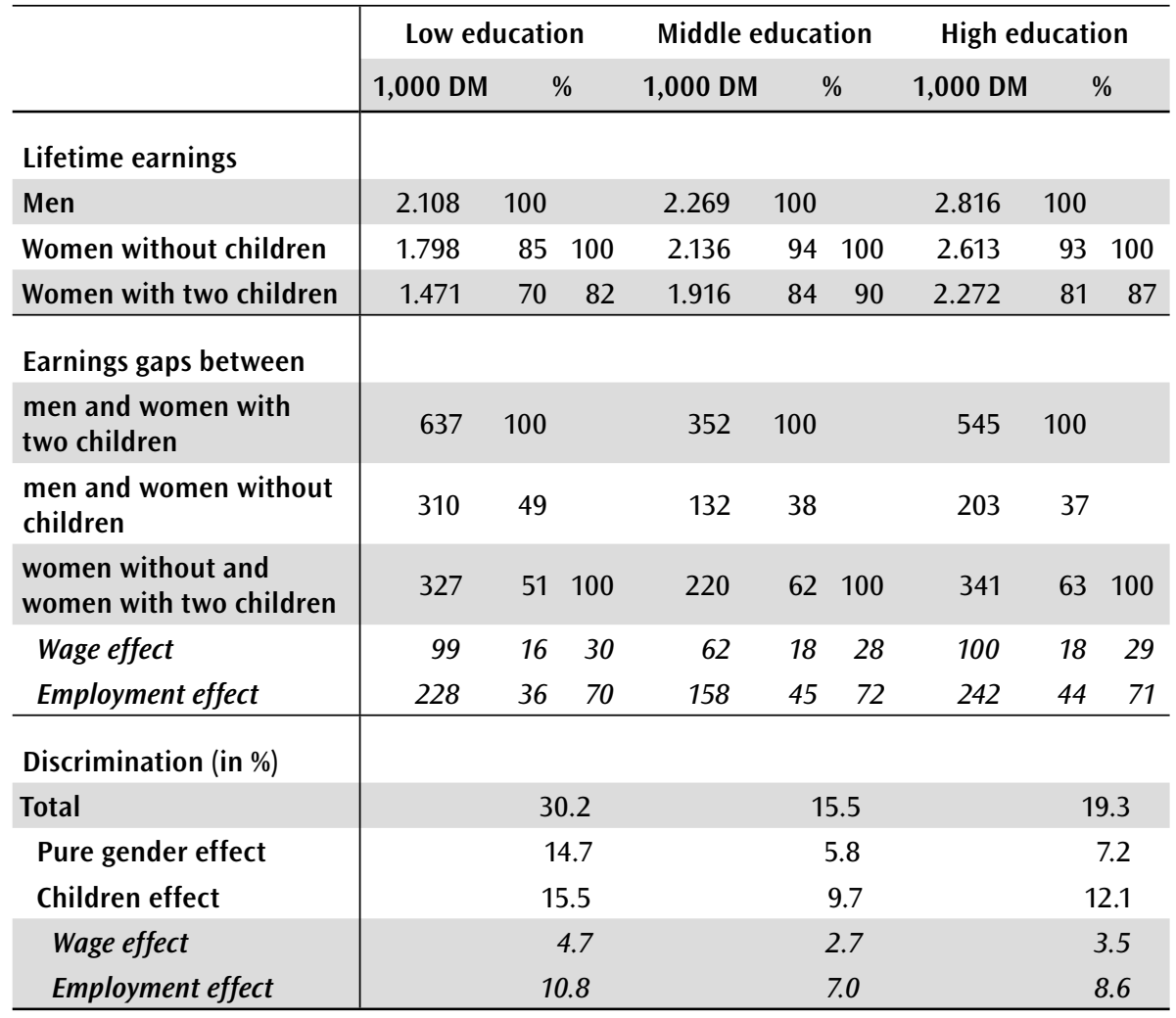

Source: Strengmann-Kuhn/Seel 2004: 66, data basis: SOEP I99I-2000, Germans residing in western Germany

In sum, the differences between the lifetime earnings of women with children and those without lies between 220,000 DM (intermediate education) and over 300,000 DM (low 
and high education). For all education groups, about 70 per cent of this is caused by the direct employment effect, and 30 per cent by the indirect wage effect. The child effect and the pure gender effect together result in a total gender earnings gap (the difference between lifetime earnings of men compared to those of women with children) of about 352,000 DM (or 15.5 per cent) for middle education and about 637,000 DM (or 30.2 per cent) for low education. However, it must be stressed again that these earnings courses are simulated for comparatively positive assumptions. If problems existing in reality were considered, the differences would be even larger.

So far we have looked at individual gross earnings. To investigate the relationship to income poverty it is necessary to analyse net income and household income rather than gross individual income. To investigate the consequences of the simulated earnings courses on poverty risk, we look at the courses of equivalent income and distinguish between equivalent earnings, equivalent pre-transfer income (i.e. after taxes), and net equivalent income, for which a child allowance and a parental allowance are simulated. For the calculation of equivalent income the original OECD scale is used.

Figure 6: Simulated Monthly Equivalent Income of Low-educated Women Without Children and With Two Children (in DM)
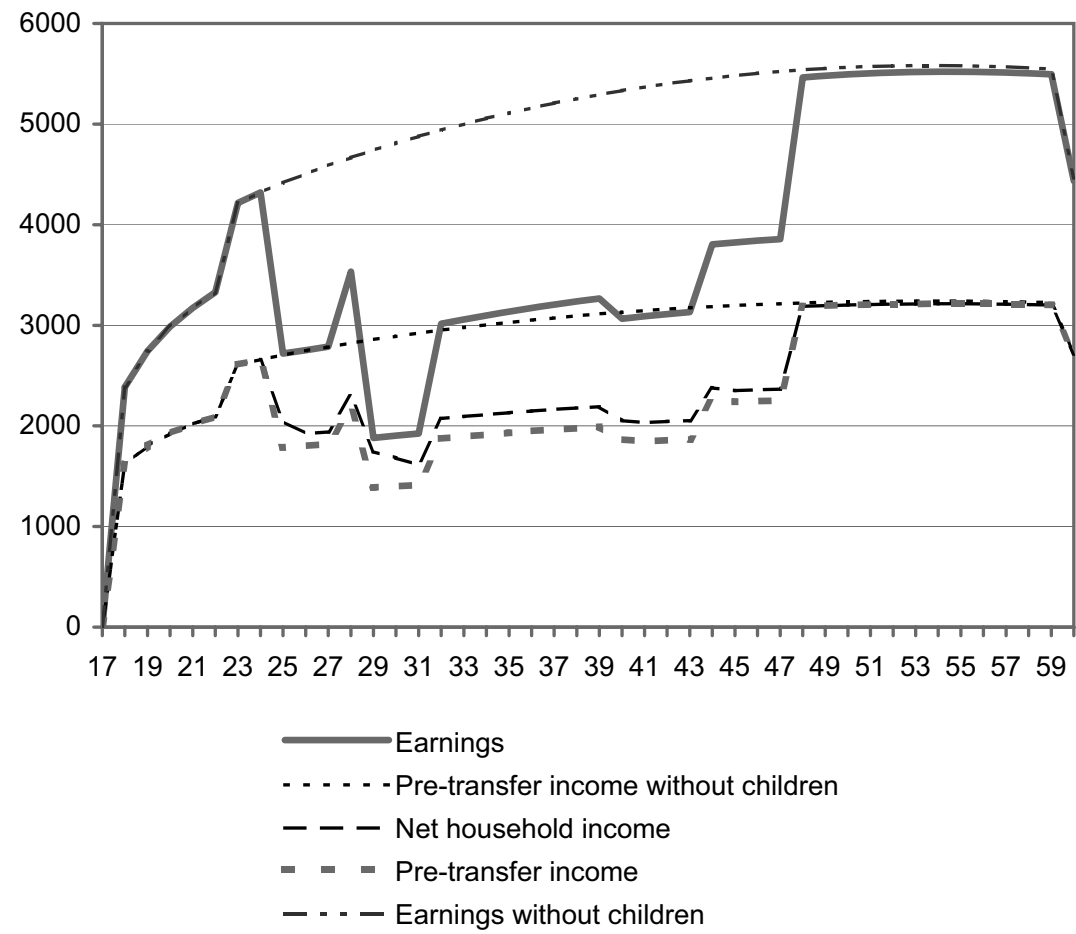

Source: Strengmann-Kuhn/Seel 2004: 83, data basis: SOEP I99I-2000, Germans residing in western Germany 
Figure 6 shows the development of equivalent income over the life cycle. Since men and women have the same income after marriage, gender-specific differences exist only in the previous period. Therefore we focus in the following on women and the differences between women with and without children, as these are identical to those of fathers and childless men after marriage. One can see in figure 6 that income differences between families and childless couples are indeed reduced by the tax system. On the other hand, after-tax income is so low after the birth of the second child that it lies below the poverty line of about I,200 DM. Poverty is avoided only through state transfers. Again it must be stressed that, first, our simulation assumes "typical«, unproblematic life courses, and that even minor negative deviations may lead to poverty, and, second, that we do not look at the group with the lowest education level, namely those who did not complete school or vocational training.

Figure 7: Simulated Monthly Equivalent Income of Intermediate-educated Women Without Children and With Two Children (in DM)

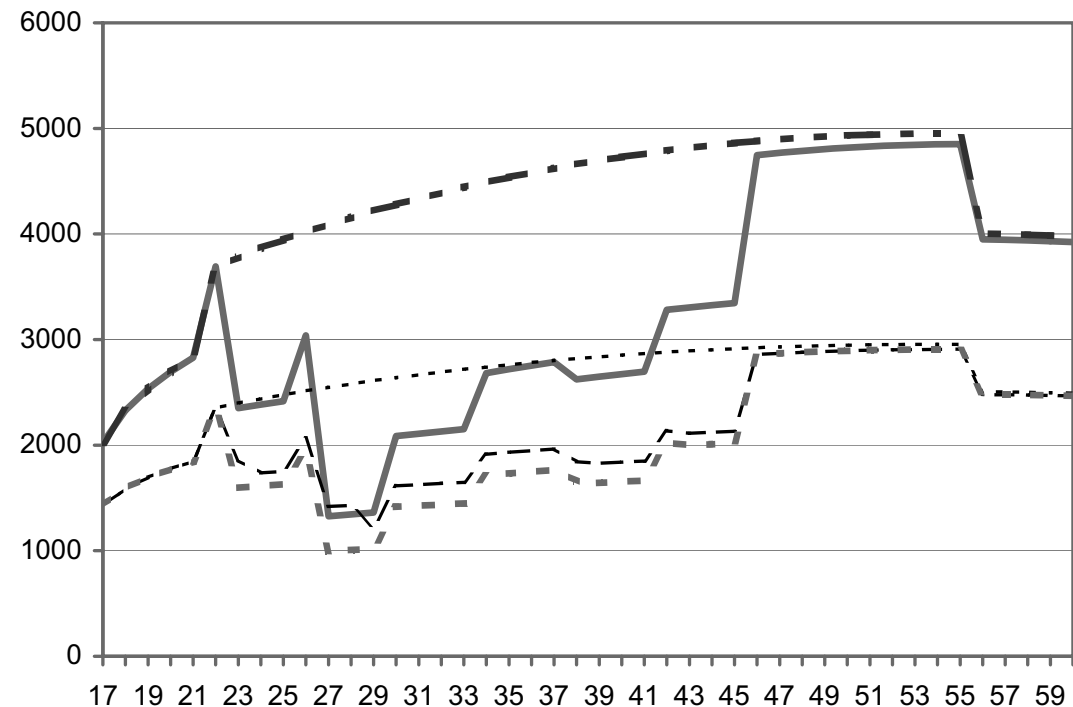

Earnings

... . - Pre-transfer income without children

- - - Net household income

- - Pre-transfer income

- Earnings without children

Source: Strengmann-Kuhn/Seel 2004: 84, data basis: SOEP I99I-2000, Germans residing in western Germany

Even with intermediate education (see figure 7), pre-transfer income is only slightly above the poverty line, and with additional child and parental allowances the resulting income is 
raised only to the zone of what Hübinger (1996) called "precarious welfare", which means an income below 75 per cent of the average, which usually entails major reductions in the standard of living.

\section{Conclusion}

The simulations showed that even with school completed, vocational training and comparatively straight, unproblematic life courses, family income lies near the poverty line during at least some periods in the life course, and that even with intermediate education there is a relevant risk of poverty. This is explained by mothers' reduced earnings, which are compensated by state transfers, but not to an extent sufficient to avoid poverty. The result of the investigations showed that gender inequalities are an important source of poverty, which often is not connected with unemployment.

In principle, fathers can rear children as well as mothers (with the exception of nursing), and even the duties of caring for a baby can be shared. There are many reasons why it is typically mothers, and not fathers, who reduce work for child rearing (StrengmannKuhn/Seel 2004: 25 ff.). A woman's decision against employment has structural and economic reasons, for example wage differences between men and women, incentives in the tax and transfer system, and a lack of public and private child-care facilities. Besides that, traditional roles are much more common in western Germany than in other countries like France, the U.S. or the Scandinavian countries. The consequence is that there are social pressures on mothers and fathers toward a gender-specific division of labour.

One explanation is the lower earnings of women, an economic argument leading to traditional gender roles, which, in turn, further increase gender differences in earnings. Gender inequalities in wages are therefore both the cause and effect of this process, whose consequences affect not only women, but also their partners and children, who face an increased poverty risk. To escape from this vicious circle it is important to increase the female labour supply, in particular by reducing incentives for the traditional gender-specific division of labour in the tax-transfer system and by improving child-care facilities. Yet increased employment of mothers is often difficult because fathers simply spend too little time on child care or do not have the opportunity to spend more time with their children. Therefore a necessary condition for an increase in labour-market participation by mothers is a reduction in labour-market participation by fathers, which might also be in the interest of the children. Through this, there would be an improved balance of family and employment for men and women, a decrease in the gender-specific wage gap and a reduction in poverty risk for families and children. However, such conditions for higher labour-market participation by women cannot be created all at once. Moreover, parents should have the right to reduce labour supply to rear children without great financial disadvantage and without an increased poverty risk. Therefore improved support for families through state transfers is still necessary (Strengmann-Kuhn 2006). 


\section{References}

Atkinson, Tony/Cantillon, Bea/Marlier, Eric/Nolan, Brian (2002): Social Indicators: The EU and Social Inclusion, Oxford: Oxford University Press

Beblo, Miriam / Wolf, Elke (2000): How Much Does a Year Off Cost? Estimating the Wage Effects of Employment Breaks and Part-Time Periods, ZEW Discussion Paper, No. oo-69, Mannheim

Beblo, Miriam/Wolf, Elke (2002): Wage Penalties for Career Interruptions. An Empirical Analysis for West Germany, ZEW Discussion Paper, No. 02-45, Mannheim

Becker, Irene / Hauser, Richard (in collaboration with Kortmann, Klaus / Mika, Tatjana/Strengmann-Kuhn, Wolfgang) (2005): Dunkelziffer der Armut. Ausmaß und Ursachen der Nichtinanspruchnahme zustehender Sozialhilfeleistungen, Berlin: edition sigma

BMGS (Bundesministerium für Gesundheit und soziale Sicherung) (2005): Lebenslagen in Deutschland. Der 2. Armuts- und Reichtumsbericht der Bundesregierung, Berlin, http://www.bmgs.bund.de/deu/gra/publikationen/p_i9.php

Burri, Stefan (I998): Methodische Aspekte der Armutsforschung, Bern/Stuttgart/Vienna: Haupt Verlag

Hagenaars, Aldi J.M. (1986): The Perception of Poverty, Amsterdam: North Holland

Hagenaars, Aldi J.M./van Praag, Bernard M.S. (1985): A Synthesis of Poverty Definitions, in: Review of Income and Wealth, Vol. 3I, No. 2, pp. 139-I54

Hauser, Richard / Becker, Irene (2004): Verteilung der Einkommen I999-2003. Gutachten für den zweiten Armuts- und Reichtumsbericht der Bundesregierung, Berlin

Hauser, Richard/Strengmann-Kuhn, Wolfgang (2004): Armut der älteren Bevölkerung in den Ländern der Europäischen Union, DRV-Schriften des Verbandes der Rentenversicherungsträger (VDR), Band 54, Frankfurt a.M.: Verband der Rentenversicherungsträger

Hübinger, Werner (1996): Prekärer Wohlstand. Neue Befunde zu Armut und sozialer Ungleichheit, Freiburg: Lambertus Verlag

Jenkins, Stephen (I99I): Poverty Measurement and the Within Household Distribution: Agenda for Action, in: Journal of Social Policy, Vol. 20, No. 4, pp. 457-483

Kayser, Hilke/ Frick, Joachim R. (200I): Take It or Leave It: (Non-) Take-Up Behavior of Social Assistance in Germany, in: Schmoller's Jahrbuch - Journal of Applied Social Science Studies, Vol. I2I, No. I, pp. 27-58

Mack, Joana / Lansley, Stewart (1985): Poor Britain, London: Allen and Unwin

Ruspini, Isabella (1998): Women and Poverty Dynamics: The Case of Germany and Britain, in: Journal of European Social Policy, Vol. 8, No. 4, pp. 29I-3I6

Seel, Barbara (2002): Armut und Umverteilung im Haushalt durch Haushaltsproduktion, Universität Hohenheim, Institut für Haushalts- und Konsumökonomik, Arbeitsbericht, No. 3

Sen, Amartya K. (1981): Poverty and Famines. An Essay on Entitlement and Deprivation, Oxford: Clarendon Press

Statistisches Bundesamt (2004): Sozialhilfe - Hilfe zum Lebensunterhalt, Fachserie 13, Reihe 2.I-2003, Wiesbaden: Statistisches Bundesamt 
Strengmann-Kuhn, Wolfgang (2003): Armut trotz Erwerbstätigkeit. Analysen und sozialpolitische Konsequenzen, Frankfurt a.M.: Campus Verlag

Strengmann-Kuhn, Wolfgang (2004): Poverty Measurement with the European Community Household Panel, Paper presented at the ChangeQual (the Economic Change, Unequal Life-Chances and Quality of Life research network funded by the DG Research, 5th Framework Programme) meeting May, Paris

Strengmann-Kuhn, Wolfgang (2006): Vermeidung von Kinderarmut in Deutschland durch finanzielle Leistungen, in: Zeitschrift für Sozialreform/Journal of Social Policy Research, Vol. 52, No. 4, pp. 439-466

Strengmann-Kuhn, Wolfgang/Seel, Barbara (2004): Einkommensdiskriminierung und frauenspezifische Erwerbsbiographie, Aachen: Shaker Verlag 